\title{
Polydesmus denticulatus C.L. Koch, 1847, vs Polydesmus denticulatus Leguillou, 1841 (Diplopoda, Polydesmida): conservation of usage and precedence of the combination Polydesmus denticulatus C.L. Koch, 1847, with a proposal to remove homonymy and suppress the combination Polydesmus denticulatus Leguillou, 1841
}

\begin{abstract}
J.-J. Geoffroy ${ }^{1}$, S.I. Golovatch ${ }^{2}$
${ }^{1}$ Muséum national d'Histoire naturelle, DSE, Site de Brunoy, 4 Avenue du Petit Château F-91800 Brunoy, France.E-mail: geoffroy@mnhn.fr

${ }^{2}$ Institute for Problems of Ecology and Evolution, Russian Academy of Sciences, Leninsky prospekt 33, Moscow 119071, Russia.E-mail: sgolovatch@yandex.ru

ABSTRACT. The purpose of this work, under Articles 23.9.1.1, 23.9.1.2, 23.9.2, 52.5, 54.4 and 82.2.1 of the International Code of Zoological Nomenclature, is to conserve the specific combination and authority Polydesmus denticulatus C.L. Koch, 1847, which is in widespread use for a millipede species belonging to the family Polydesmidae. The name is jeopardized by a little-used senior homonym, Polydesmus denticulatus Leguillou, 1841, that actually belongs to the family Platyrhacidae. It is proposed that Polydesmus denticulatus C.L. Koch, 1847 is given precedence as a nomen protectum over Polydesmus denticulatus Leguillou, 1841 that is considered to be a nomen oblitum.

How to cite this article: Geoffroy J.-J., Golovatch S.I. 2016. Polydesmus denticulatus C.L. Koch, 1847, vs Polydesmus denticulatus Leguillou, 1841 (Diplopoda, Polydesmida): conservation of usage and precedence of the combination Polydesmus denticulatus C.L. Koch, 1847, with a proposal to remove homonymy and suppress the combination Polydesmus denticulatus Leguillou, 1841 // Invert. Zool. Vol.13. No.1. P.57-60. doi: 10.15298/ invertzool.13.1.05
\end{abstract}

KEY WORDS: Diplopoda, Polydesmida, nomenclature, homonymy, taxonomy, Polydesmidae, Polydesmus, Polydesmus denticulatus, Europe, New Guinea. 


\title{
Polydesmus denticulatus C.L. Koch, 1847, против Polydesmus denticulatus Leguillou, 1841 (Diplopoda, Polydesmida): сохранение использования и примат комбинации Polydesmus denticulatus C.L. Koch, 1847, с предложением устранить омонимию и отвергнуть комбинацию Polydesmus denticulatus Leguillou, 1841
}

\author{
Ж.-Ж. Жофрфруа ${ }^{1}$, С.И. Головач²
}

\footnotetext{
${ }^{1}$ Национальный музей естественной истории, Брюнуа, Франция.

${ }^{2}$ Институт проблем экологии и эволючии РАН, Ленинский проспект, 33, Москва 119071 Россия
}

РЕЗЮМЕ. Согласно пунктам 23.9.1.1, 23.9.1.2, 23.9.2, 52.5, 54.4 и 82.2.1 Международного кодекса зоологической номенклатуры, предлагается сохранить примат видовой комбинации Polydesmus denticulatus C.L. Koch, 1847, широко используемой для обозначения вида диплопод из семейства Polydesmidae. Этому названию угрожает малоиспользуемый старший омоним Polydesmus denticulatus Leguillou, 1841, который на самом деле относится к семейству Platyrhacidae. Предлагается отдать приоритет Polydesmus denticulatus C.L. Koch, 1847 в качестве защищенного названия (nomen protectum) по отношению к биномену Polydesmus denticulatus Leguillou, 1841, который считается забытым названием (nomen oblitum).

Как цитировать эту статью: Geoffroy J.-J., Golovatch S.I. 2016. Polydesmus denticulatus C.L. Koch, 1847, vs Polydesmus denticulatus Leguillou, 1841 (Diplopoda, Polydesmida): conservation of usage and precedence of the combination Polydesmus denticulatus C.L. Koch, 1847, with a proposal to remove homonymy and suppress the combination Polydesmus denticulatus Leguillou, 1841 // Invert. Zool. Vol.13. No.1. P.57-60. doi: 10.15298/ invertzool.13.1.05

КЛЮЧЕВЫЕ СЛОВА: Diplopoda, Polydesmida, номенклатура, омонимия, таксономия, Polydesmidae, Polydesmus, Polydesmus denticulatus, Европа, Новая Гвинея. 


\section{Introduction}

C.L. Koch (1847: 135) described Polydesmus denticulatus as a new European millipede species, but was quite unware that the same combination had been used earlier by Leguillou (1841: 279) for a totally different taxon described from New Guinea.

Latzel (1884: 141, 143) noticed this homonymy for the first time, but considered that the species belonged to a different genus. He assigned it to the genus Stenonia Gray, 1843 in his own sense; actually this is a composite genus that encompassed species belonging to several families. Latzel decided to use $P$. denticulatus C.L. Koch, and so did all authors after him, since 1884 up to now. However, the principle of homonymy of the International Code of Zoological Nomenclature (1999) prescribes to solve such a case.

\section{The case}

The reasons for such a work and resolution have long been put forth by Jeekel (2000: 95, 96). To solve the case, a first option is to simply abolish the name denticulatus C.L. Koch as invalid and replace it by its subjective synonym P. scabratus C.L. Koch, 1847, selecting its neotype because the type material is lost. An alternative is to suppress the name $P$. denticulatus Leguillou for the purpose of both the Principle of Homonymy and the Principle of Priority, the name $P$. denticulatus C.L. Koch, 1847 being used as valid.

The present situation has somewhat aggravated since the rediscovery of the holotype and unique specimen - of $P$. denticulatus Leguillou, 1841 in the collection of the Muséum national d'Histoire naturelle (MNHN) in Paris, France, which actually is a juvenile Platyrhacidae (MNHN JB 250). So we strongly recommend, under Articles 52.5, 54.4 and 82.2.1 of the Code, to officially suppress the use of the combination Polydesmus denticulatus Leguillou, 1841, and to favour the use of $P$. denticulatus in the sense of C.L. Koch, 1847, a very common and widely distributed European mil- lipede, very often cited in the literature, checklists and databases.

The senior homonym Polydesmus denticulatus Leguillou, 1841 has only been used twice, by Leguillou (1841) and Latzel (1884), and has never since been utilized as a valid name. The junior homonym Polydesmus denticulatus C.L. Koch, 1847 has been used for a particular taxon as its valid name in innumerable (much more than 25) works, published by many authors (much more than 10) in the immediately preceding 50 years and encompassing a span of not less than 10 years. To our knowledge, all conditions of articles 23.9.1.1, 23.9.1.2 and 23.9.2 of the Code are met. So we state explicitly that the younger name Polydesmus denticulatus C.L. Koch, 1847 is considered valid and qualified by the term nomen protectum, and it has precedence over the older, but invalid name Polydesmus denticulatus Leguillou, 1841, qualified by the term nomen oblitum.

\section{Conclusion}

We formally state and propose:

- to give the name denticulatus C.L. Koch, 1847, as published in the binomen Polydesmus denticulatus, precedence over the name denticulatus Leguillou, 1841, as published in the binomen Polydesmus denticulatus, whenever the two are considered to be homonyms;

- to place or maintain on the Official List of Specific Names in Zoology the name denticulatus, as published in the binomen Polydesmus denticulatus C.L. Koch,1847; qualified by the term nomen protectum.

- to place on the Official Index of Rejected and Invalid Specific Names in Zoology the name denticulatus Leguillou, 1841, as published in the binomen Polydesmus denticulatus (unused senior homonym of $P$. denticulatus C.L. Koch, 1847); qualified by the term nomen oblitum.

ACKNOWLEDGEMENTS. We are particularly grateful to Dr. Mark Judson (MNHN Paris) for his most valuable comments. Special thanks go to the MNHN administration for fi- 
nancing the second author's stay in Paris in April 2016.

\section{References}

International Commission on Zoological Nomenclature 1999. International Code of Zoological Nomenclature (Fourth Edition). London: International Trust for Zoological Nomenclature, The Natural History Museum. $306 \mathrm{pp}$.

Jeekel C.A.W. 2000. Polydesmus denticulatus C.L. Koch, 1847, versus Polydesmus denticulatus Leguillou, 1841
(Diplopoda, Polydesmida) // Myriapod Memoranda. Vol.2. P.94-95.

Koch C.L. 1847. System der Myriapoden // L. HerrichSchäffer (Hrgb.). Kritische Revision der Insectenfauna Deutschlands. Regensburg: Pustet. Bd.3. 270 S.

Latzel R. 1884. Die Myriopoden der österreichisch-ungarischen Monarchie. Zweite Hälfte. Wien: Hölder. $\mathrm{xii}+414 \mathrm{~S}$.

Leguillou E.J.F. 1841. Catalogue raisonné des Insectes recueillis pendant le voyage de circumnavigation des Corvettes l'Astrolabe et la Zélée // L'Institut. T.9. P.279-280.

Responsible editor K.G. Mikhailov 